ORIGINAL ARTICLE

\title{
TRENDS IN THE RESISTANCE PATTERN OF BACTERIAL PATHOGENS OF OTITIS MEDIA IN IBADAN, NIGERIA.
}

\author{
A.O. Okesola \& O.A. Fasina \\ Department of Medical Microbiology \& Parasitology, College of Medicine,University of Ibadan, \\ University College Hospital, Ibadan, Nigeria, \\ * Correspondence:: Dr A.O. Okesola, Department of Medical Microbiology and Parasitology, \\ College of Medicine,University of Ibadan, Ibadan, Nigeria. Tel:234-803-305-0593. E-mail \\ :abiolaokesola@yahoo.com/aookesola@comui.edu.ng
}

\begin{abstract}
Otitis media, an inflammation of the middle ear, is a common illness in childhood, and also one of the most frequent reasons for outpatient antimicrobial therapy. This study was undertaken to determine the bacterial etiology of otitis media in our environment and their pattern of antibiotic susceptibility. Between November 2009 and March 2011, ear swabs collected from 132 patients with clinical diagnosis of acute otitis media and chronic suppurative otitis media were subjected to bacteriological analysis. The bacterial pathogens isolated were tested against ten antibiotics using standard bacteriologic techniques.

A total of 142 isolates were recovered from the 132 patients involved in this study. The most frequently isolated organism in acute otitis media and chronic suppurative otitis media was Pseudomonas aeruginosa, $(43.7 \%)$, followed by Klebsiella species $(31.0 \%)$, Proteus species (14.1\%), Escherichia coli $(7 \%)$, H.influenzae $(2.8 \%)$ and Staphylococcus aureus $(\mathbf{1 . 4} \%)$. Generally, high resistance rates were recorded against many of the antibiotics tested. However, ciprofloxacin demonstrated the highest susceptibility rates for P.aeruginosa $(77.4 \%)$ and Klebsiella species (59.1\%).All the pathogens demonstrated nil susceptibility towards cefixime except E.coli where the susceptibility rate was $40 \%$.In conclusion, determination of the susceptibility pattern of bacterial pathogens of otitis media is of utmost importance to its effective management.
\end{abstract}

Key words: Otitis media, bacterial pathogens, resistance pattern

\section{INTRODUCTION}

Otitis media (OM) is the inflammation of the middle ear, which may be caused by bacteria, fungi or viruses. There are three types of otitis media, and these are, acute purulent otitis media, otitis media with effusion and chronic suppurative otitis media (1).Acute bacterial infection of the middle ear normally originates from an upper respiratory tract infection with the bacteria entering by the auditory (Eustachian) tube, which is the principal portal of entry of pathogens into the ear (2).

Chronic suppurative otitis media (CSOM) is defined as a chronic inflammation of the middle ear and mastoid cavity, which presents with recurrent ear discharges through a tympanic perforation(3).Effusion of OM may be serous, mucoid or purulent (4). Otitis media may be associated with infection or may be sterile. The sterile variety is usually called serous OM and is often attributed to allergy, but may also occur from numerous other potential sources including radiation treatment or virus $(5,6)$.

Otitis media is very common in childhood and is almost always accompanied by a viral upper respiratory infection (URI) with a peak incidence between 4-7 years of age (7). Seventy-five percent of children experience at least one episode by their third birthday. Almost half of these children will have 3 or more ear infections during their first 3 years. The reason for the higher frequency in these populations is the anatomic differences in skull base and Eustachian tube and biologic susceptibility (8). Although $\mathrm{OM}$ is primarily a disease of infants and young children, it can also affect adults (9). Furthermore, the incidence is higher in males than in females (10).

The significant risk factors in $\mathrm{OM}$ include socioeconomic status, cultural, seasonal, and age factors, as well as family history of middle ear disease (11). 
The most common bacterial pathogens of OM are Streptococcus pneumoniae, Hemophilus influenzae and Moraxella catarrhalis (12). Other pathogens responsible for OM are Staphylococcus aureus, Escherichia coli, Klebsiella species, Pseudomonas aeruginosa and Proteus species (13). The types of pathogens involved in OM have also been found to be dependent on geographical location (14). The aim of this study was therefore to determine the bacterial etiology of $\mathrm{OM}$ in this environment and their susceptibility pattern to the available antibiotics.

\section{MATERIALS AND METHODS}

This is a laboratory-based study carried out between November 2009 and March 2011 at the Medical Microbiology Laboratory of University College Hospital (UCH), Ibadan, Nigeria.

One hundred and thirty-two ear swabs which were collected from patients with clinically diagnosed acute otitis media and chronic suppurative otitis media at the otolaryngology clinic of UCH were included in this study. Bacterial pathogens of acute otitis media and CSOM were isolated and identified from these aural swabs using standard bacteriological methods. They were subsequently subjected to antimicrobial susceptibility testing according to the recommendation of the Clinical and Laboratory Standards Institute (CLSI) for disc diffusion tests (15). The susceptibility pattern of the bacterial pathogens were determined towards the following antimicrobial agents, ciprofloxacin, gentamycin, pefloxacin, ofloxacin, ceftriaxone, cefuroxime, ceftazidime, amikacin, amoxycillin/clavulanate, and cefixime. The diameters of zones of inhibition around the bacterial colonies were measured with a calibrated ruler and interpreted as susceptible or resistant using an interpretive chart (15).

\section{RESULTS}

Aural swabs obtained from 132 patients with clinical diagnosis of CSOM and OM were included in this study. Seventy $(53 \%)$ of these patients were males while $62(47 \%)$ were females. Among these, 80(60.6\%) were diagnosed as CSOM while $52(39.4 \%)$ were diagnosed as OM. The age distribution of the patients are demonstrated in Table 1.
Table 1.Distribution of otitis media by age and sex

\begin{tabular}{|l|l|}
\hline Age (Years) & No (\%) \\
\hline$<10$ & $62(47.0)$ \\
\hline $10-20$ & $30(22.7)$ \\
\hline $21-40$ & $18(13.6)$ \\
\hline $41-60$ & $8(6.1)$ \\
\hline$>60$ & $6(4.6)$ \\
\hline *Unspecified & $8(6.1)$ \\
\hline Total & $132(100.0)$ \\
& \\
\hline Sex & $70(53.0)$ \\
\hline Male & $62(47.0)$ \\
\hline Female & $132(100.0)$ \\
\hline Total &
\end{tabular}

*Study patients gave estimated ages which may

not be accurate, hence classified as "unspecified".

A single pathogen was demonstrated in $120(90.9 \%)$ patients, two in $10(7.6 \%)$ and no growth in $2(1.5 \%)$. The double pathogens were demonstrated in $4(80 \%)$ patients with CSOM and $1(20 \%)$ with OM.

Pseudomonas aeruginosa was the most frequently isolated in both CSOM and OM while S.aureus 2 $(1.4 \%)$, was the least commonly isolated. The frequency of isolation of the bacterial pathogens in CSOM and OM are demonstrated in Table 2.

Table 2. Distribution of bacteria pathogens in otitis media.

\begin{tabular}{|l|l|l|l|}
\hline Bacterial Pathogens & CSOM & OM & $\begin{array}{l}\text { Total } \\
\text { No (\%) }\end{array}$ \\
\hline Klebsiella species & 24 & 20 & $\begin{array}{l}44 \\
(31.0 \%)\end{array}$ \\
\hline $\begin{array}{l}\text { Pseudomonas } \\
\text { aeruginosa }\end{array}$ & 40 & 22 & $62(43.7)$ \\
\hline Proteus species & 12 & 8 & $20(14.1)$ \\
\hline Escherichia coil & 8 & 2 & $10(7.0)$ \\
\hline Staphylococcus aureus & 2 & - & $2(1.4)$ \\
\hline Hemophilus influenzae & 4 & - & $4(2.8)$ \\
\hline Total & 90 & 52 & $\begin{array}{l}142 \\
(100.0)\end{array}$ \\
\hline
\end{tabular}

CSOM - Chronic suppurative otitis media

OM - Acute otitis media. 
From 132 patients with CSOM and OM, a total of 142 bacterial pathogens were isolated. Of these, $140(98.6 \%)$ were Gram-negative bacilli and 2 (1.4\%),Gram-positive cocci.Pseudomonas aeruginosa 62(44.3\%) and Klebsiella species $44(31.4 \%)$ were the most prevalent among the Gram-negative pathogens. S.aureus was the only Gram-positive pathogen isolated.
Of the ten antibiotics tested against these bacterial pathogens, ciprofloxacin had the highest susceptibility rates for $P$. aeruginosa $(77.4 \%)$ and Klebsiella species (59.1\%). Cefixime demonstrated nil $(0 \%)$ susceptibility to all the pathogens except E.coli where the susceptibility rate was $40 \%$. The antibiotic susceptibility profiles of the various pathogens isolated are shown in Table 3.

Table 3. Antibiotic susceptibility pattern of bacterial pathogens of otitis media

\begin{tabular}{|l|l|l|l|l|l|l|}
\hline Antibiotics & \multicolumn{5}{|c|}{ Susceptibility pattern of isolates } \\
\hline & $\begin{array}{l}\text { Sseud } \\
\mathrm{N}=62\end{array}$ & $\begin{array}{l}\text { Kleb } \\
\mathrm{N}=44\end{array}$ & $\begin{array}{l}\text { Proteus } \\
\mathrm{N}=20\end{array}$ & $\begin{array}{l}\text { E.coli } \\
\mathrm{N}=10\end{array}$ & $\begin{array}{l}\text { S.aureus } \\
\mathrm{N}=2\end{array}$ & $\begin{array}{l}\text { H.inf } \\
\mathrm{N}=4\end{array}$ \\
\hline & No (\%) & No $\%)$ & No $\%)$ & No (\%) & No (\%) & No (\%) \\
\hline Ciprofloxacin & $48(77.4)$ & $26(59.1)$ & $6(30.0)$ & $4(40.0)$ & $2(100.0)$ & $2(50.0)$ \\
\hline Gentamycin & $40(64.5)$ & $20(45.5)$ & $10(50.0)$ & $2(20.0)$ & $2(100.0)$ & $2(50.0)$ \\
\hline Pefloxacin & $24(38.7)$ & $8(18.2)$ & $2(10.0)$ & $4(40.0)$ & $0(0.0)$ & $0(0.0)$ \\
\hline Ofloxacin & $36(58.1)$ & $26(59.1)$ & $10(50.0)$ & $0(0.0)$ & $2(100.0)$ & $2(50.0)$ \\
\hline Ceftriaxone & $16(25.8)$ & $20(45.5)$ & $14(70.0)$ & $4(40.0)$ & $0(0.0)$ & $2(50.0)$ \\
\hline Cefuroxime & $4(6.5)$ & $16(36.4)$ & $4(20.0)$ & $4(40.0)$ & $0(0.0)$ & $4(100.0)$ \\
\hline Ceftazidime & $42(67.7)$ & $10(22.7)$ & $6(30.0)$ & $4(40.0)$ & $0(0.0)$ & $0(0.0)$ \\
\hline Amikacin & $26(41.9)$ & $4(9.1)$ & $0(0.0)$ & $2(20.0)$ & $0(0.0)$ & $0(0.0)$ \\
\hline Augmentin & $0(0.0)$ & $12(27.3)$ & $0(0.0)$ & $0(0.0)$ & $2(100.0)$ & $4(100.0)$ \\
\hline Cefixime & $0(0.0)$ & $0(0.0)$ & $0(0.0)$ & $4(40.0)$ & $0(0.0)$ & $0(0.0)$ \\
\hline
\end{tabular}

Augmentin-Amoxycillin/clavulanate

\section{DISCUSSION}

In this study, P.aeruginosa (43.7\%) was found to be the most prevalent bacterial pathogen of $\mathrm{OM}$ and CSOM in this environment, followed by Klebsiella species (31\%), Proteus mirabilis (14.1\%), Escherichia coli $(7 \%), H$. influenzae $(2.8 \%)$ and S.aureus $(1.4 \%)$. The preponderance of P.aeruginosa in this study is in agreement with a study conducted by Kawo et al in the Northern part of Nigeria (16). In contrast, however, in a study conducted in Iran, the most frequently isolated pathogen of OM was $S$. aureus followed by P.aeruginosa and Proteus species (17). In the United States of America, Israel and Eastern Europe, the commonest bacterial pathogens of OM were Streptococcus pneumoniae, H.influenzae and Moraxella catarrhalis (14).

In the present study, the peak incidence was found in the age group $0-10$ years $(47 \%)$, followed by $10-20$ years $(22.7 \%)$, and a decline with advancement in age (Table 1). This has been attributed to the shorter, wider, and horizontal Eustachian tube in children than in adults, offering greater opportunities for pathogens to ascend from nasopharynx to the sterile middle ear cavity (18).

The frequency of double causative agents $(7.6 \%)$ was much lower than single causative agent $(90.9 \%)$. This contradicts the report of Alsaimary where the frequency of double causative agents was higher than single causative agent (19). The incidence rate of otitis media is higher in males $(53 \%)$ than females $(47 \%)$ which agrees with the finding of another study elsewhere (10). 
Many antimicrobial agents have been used for the treatment of OM infection and these include penicillin, cephalosporins, vancomycin and azithromycin. However, bacterial resistance to these antimicrobials has become an increasing problem in the treatment of otitis media (19). In this study, the most effective antimicrobial agent against P.aeruginosa, the most prevalent etiological agent of $\mathrm{OM}$ in this environment, was ciprofloxacin $(77.4 \%)$, followed by ceftazidime $(67.7 \%)$, gentamycin $(64.5 \%)$, ofloxacin $(58.1 \%)$ and amikacin $(41.9 \%)$. The high susceptibility demonstrated towards ciprofloxacin is similar to what was reported in another study where P.aeruginosa demonstrated $100 \%$ susceptibility to ciprofloxacin(17).

\section{REFERENCES}

1. Berman S.Classiification and criteria of otitis media. Clin Microbiol Infect 1997; (suppl)3:1-4.

2. Atlas RM. Microbiology Fundamentals and Applications. Second edition Macmillan Publishing Company 1998 pp 669,638 .

3. Howard D. Intercultural commucation and conductive hearing loss. J First People Child Family Rev. 2009; 3(4): 97.

4. Abera B, Biadeglegne F. Epidemiology of otitis media. Inter $\mathrm{J}$ Paed Otolaryngol 2008; 72(6): 787-792.

5. Ahlo OP, Oja H, Koivu M, Sorri M. Risk factors for chronic otitis media with effusion in infancy, each acute otitis media episode induces a high but transient risk. Arch otolaryngol Head Neck Surg 1995; 121: 839 - 843.

6. Daly KA. Epidemiology of otitis media. Otolaryngol Clin North Am. 1991; 24:775-782.

7. Bluestone CD, Klein JO. Otitis media in infants and children, 2nd W.C.Saunders companyPhiladelphia.1995;1-3/3968/73-101/145-231.

8. Chan KH, Swarts JD, Rudoy R, Dever GJ,Yuji M. Otitis media in the republic of Palau. A case-series study. Arch otolaryngol Head Neck Surg 1993; 119:425-428.

9. GateGA.Cost-effectiveness considerations in otitis media treatment.
Generally, in this study, high resistance rates were recorded towards a number of antibiotics commonly used in this environment, and these included pefloxacin, ceftriaxone, cefuroxime, amikacin, amoxycillin/ clavulanate and cefixime.

This may be attributed to the inappropriate and indiscriminate use of these antibiotics in our environment. This calls for judicious use of antibiotics and periodical monitoring of the antibiotic resistance pattern in this region.

\section{ACKNOWLEDGEMENT}

The authors appreciate Mr Abiodun Oladijo and Mrs Abosede Agboola for their secretarial and technical assistance respectively.

Otolaryngology Head and Neck Surg 1996; 114 (4): 525 - 530.

10. Paradise JL, Rochette HE, Colborn DK, Bernard BS, Smith OG, Kurs-Lasky M et al. Otitis media in 2253 Pittsburg area infants; Prevalence and risk factors during the first two years of life. Pediatr 1997; 99; 318-333.

11. Rotowa NA, Montefiore D, AdeyemiDoro FAB. An in-vitro study in ciprofloxacin and other antimicrobials against Gram-negative bacteria isolated from patients in Ibadan, Nigeria. Afr J Med Med Sc 1989; 18: 63-67.

12. Kilpi T, Herva E, Kaijalainem T, Syrjnen R, Takala AK. Bacteriology of acute otitis media in a cohort of Finnish children followed for the first two years of life. Pediatr Infect Dis J 2001; 20: 654 - 662.

13. Klein J. Otitis media. Clin Inf Dis 1994; 823-833.

14. Jacobs MR, Dagan R; Appelbaum PC, Burch DJ. Prevalence of antimicrobialresistant pathogens in middle ear fluid; multinational study of 917 children with acute otitis media. Antimicrob Agents Chemother 1998; 42: 589 - 595.

15. Clinical and Laboratory Standards Institute (CLSI). Performance Standards for Antimicrobial Susceptibility Testing. 7th ed Wayne (PA); CLSI; 2007. 
16. Kawo AH, Daiyah BM, Yusha'u M. Susceptibility patterns of bacterial pathogens associated with otitis media at Murtala Muhammed Specialist Hospital, Kano, Nigeria. Int J Pharm App Sc 2010; 1: 74-78.

17. Ettehad G, Refahi S, Nemmati A, Pirzadeh A, Daryani A. Microbial and antimicrobial susceptibility patterns from patients with chronic otitis media in Ardebl. Int J Trop Med 2006; 1(2): 62 - 65.
18. Bluestone CD, Klein JO. Microbiology. In: Bluestone CD, Klein JO, eds. Otitis media in infants and children. $3^{\text {rd }}$ ed. Philadelphia, PA: W.B. Saunders 2001, pp 79-1014.

19. Alsaimary IE, Alabbasi AM, and Najim JM. Antibiotics susceptibility of bacterial pathogens associated with otitis media. J Bact Res 2010; 2(4): 41-50. 